This item was submitted to Loughborough's Research Repository by the author.

Items in Figshare are protected by copyright, with all rights reserved, unless otherwise indicated.

\title{
European anti-austerity and pro-democracy protests in the wake of the global financial crisis
}

PLEASE CITE THE PUBLISHED VERSION

https://doi.org/10.1080/14742837.2016.1256193

\section{PUBLISHER}

(C) Taylor \& Francis (Routledge)

\section{VERSION}

AM (Accepted Manuscript)

\section{PUBLISHER STATEMENT}

This work is made available according to the conditions of the Creative Commons Attribution-NonCommercialNoDerivatives 4.0 International (CC BY-NC-ND 4.0) licence. Full details of this licence are available at: https://creativecommons.org/licenses/by-nc-nd/4.0/

\section{LICENCE}

CC BY-NC-ND 4.0

\section{REPOSITORY RECORD}

Fominaya, Cristina Flesher. 2016. "European Anti-austerity and Pro-democracy Protests in the Wake of the Global Financial Crisis”. Loughborough University. https://hdl.handle.net/2134/33702. 
This is a pre-print versión Please do not cite. To cite this paper please refer to the published version available here:

https://www.tandfonline.com/doi/abs/10.1080/14742837.2016.1256193

\section{European anti-austerity and pro-democracy protests in the wake of the global financial crisis}

\section{Cristina Flesher Fominaya}

\section{Introduction}

European anti-austerity and pro-democracy movements form part of a global wave of protests following the global financial crisis. Waves (or "cycles of contention") are characterized by a rapid diffusion of collective action, innovation in forms of contention, shared new major frames of meaning, discourse and action, the incorporation of new unorganized actors with organized actors, and increased contention between challengers and authorities (Tarrow, 1998). Waves follow periods of expansion (across social groups, sectors, policy areas, and sometimes borders), transformation (of strategies, alliance structures, identities) and finally, contraction or subsidence (Koopmans, 2004).

In the heady early days of protests and occupations observers, pundits and scholars were quick to offer theories to explain what was happening, many of which centered around claims of newness, spontaneity, and the unprecedented (Flesher Fominaya, 2015a). Often those narratives were infused with excitement and optimism for progressive social change fuelled by early victories in Iceland, Egypt and Tunisia. This widespread feeling of excitement and possibility has been observed in previous waves of intense mobilization, described as "moments of madness" (Zolberg 1972) or 
This is a pre-print versión Please do not cite. To cite this paper please refer to the published version available here: https://www.tandfonline.com/doi/abs/10.1080/14742837.2016.1256193 the "eros effect" (Katsiaficas 1989). Once waves enter into subsidence (at least in some places) or suffer reversals of early victories, we are able to better evaluate some of the early explanations in light of their diverse trajectories and outcomes.

In this article, I will analyze the key features of this European wave of mobilizations, drawing on the extensive existing literature and insights from my own research on anti-austerity mobilization in Spain and Irelandi, and focusing primarily, but not exclusively, on Southern Europe and the movements of the squares. I proceed in five parts. In section one, I argue that although the economic crisis and attendant increases in social-economic inequalities and hardship provide a crucial motivating factor for protests against austerity, they are insufficient to explain mobilization - a fact borne out by the strong differences in collective responses to austerity in those countries hardest hit. I argue that the financial crisis and austerity policies brought into sharp relief the longer-term crisis of legitimacy of representative democracy in Europe (Armingeon and Guthman, 2014; della Porta, 2012a, 2012b, 2013, 2015; Flesher Fominaya, 2014a, 2015a, 2015b; Langman, 2013; Norris, 2011). To the extent that these "twin" crises are framed synergistically, they can be seen as counter-hegemonic, as they seek not only to contest specific austerity policies but to rupture the (post-political) consensus around the neoliberal order underpinning the (neo)liberal state and representative democracy. In this sense, as I argue in section two, they represent a continuation of the double critique levelled by the Global Justice Movement (henceforth GJM) against neoliberal 
This is a pre-print versión Please do not cite. To cite this paper please refer to the published version available here:

https://www.tandfonline.com/doi/abs/10.1080/14742837.2016.1256193 capitalist globalization and illegitimate, ineffective representative

democracy but now framed within the aftermath of the global

financial crisis and austerity policies. As these material effects hit, the critique of the democratic deficit shifts from the supranational targets most visible in the GJM to centre on nation-state oligarchies, and protester collective identity is constructed around the political subject "citizen" and "the people". As the nation-state returns centre stage as target and focus of protest, democracy emerges as a central demand, as I show in section three. Here the critical connection between these intertwined crises (economic/financial and political) finds its clearest and most emblematic expression in the occupy-style "movement of the squares", whose consequences resonate far beyond the squares to influence mobilization across organizational forms and sectors. However, as I show in section four, their transnational resonance in uneven, and does not follow a linear progression. As I show in section five, focusing on the Spanish case, as activists and citizens contest austerity and question the legitimacy of political elites to represent them, the state responds through legal restrictions. In the face of the intransigence of national political and economic oligarchies, and the recognition of the limited impact of protest on changes in austerity policy or democratic renewal, some mobilization becomes institutionalized in the form of new hybrid parties, such as Podemos and the municipal movements. Finally, I argue that understanding the deeply political nature of these protests means recognizing the most significant potential they offer for sociopolitical transformation: austerity is still in place across Europe, but new initiatives attempting to transform "really existing democracy" have emerged. 


\section{Twin crises: financial crisis and the legitimation crisis}

\section{of representative democracy}

During this wave of European anti-austerity mobilization, longestablished political opposition cultures are being remobilized, but within a much changed political and economic context that has provided increased political opportunities for mobilization facilitated by the after-effects of the global financial crisis. In those countries most affected, the decrease in material conditions due to the impact of the crisis (e.g. rising unemployment and collapse of housing markets) have combined with austerity policies that have, inter alia, drastically cut welfare state measures to mitigate the effects of these consequences on citizens. This context has made possible a greater receptivity of the public towards the anti-neoliberal capitalist critique and the calls for greater democracy and socio-economic justice, particularly in those contexts where people experience strong effects of the crisis. It has also resulted in scholars calling for greater attention to the material bases of mobilization, or political economic opportunity structures (see Císař and Navrátil, this issue). However, a potential receptivity does not automatically translate into mass mobilizations: a network of actors willing and able to channel and mobilize those grievances is needed (Koopmans, 2004, p. 22). The countries most affected by the global crisis and the Troika's demands for economic adjustments (pejoratively denominated PIIGS) had strongly different mobilization responses: Spain and Greece having strong and sustained mobilizations, Italy, Ireland and Portugal relatively moderate ones (see Baumgarten; Kannellopoulos et. al.; and Zamponi and Fernández; all this issue). Untangling the many 
This is a pre-print versión Please do not cite. To cite this paper please refer to the published version available here: https://www.tandfonline.com/doi/abs/10.1080/14742837.2016.1256193 factors that can explain these differences is an important task for scholarship, that requires a nuanced exploration of the relationship between different political-economic configurations and patterns of protest (see e.g. Císař and Navrátil, this issue; della Porta, 2015).

As important as the global economic crisis (and the related Eurozone crisis) is, if we want to understand this European wave of contention, we must also recognize the central importance is the legitimation crisis of democracy (Habermas, 1975). Economic/financial crises provoke legitimation crises when elites are perceived as having caused and benefitted from them, and having failed to protect citizens against their worst effects (Della Porta 2012a and b, 2015; Flesher Fominaya 2015b; Langman, 2013). The financial crisis brought to a head a longer-term decline in trust, legitimacy, and satisfaction with democratic regimes, fuelled by an increase in demands for democracy (rising public aspirations for democracy), an increase in negative news about government, and an analysis of the actual performance and structure of existing democratic regimes (Norris 2011). There has been a dramatic increase in dissatisfaction with democracy in Europe since the 2007/2008 global financial crisis due to a combination of citizen perception of loss of national sovereignty and economic deterioration (Armingeon and Guthman, 2014). Economic crises and austerity policies reflect and contribute to the crisis of representative democracy (della Porta, 2012a, 2015; Flesher Fominaya 2015b) in which the recent waves of movements of the squares "are just the most visible" manifestation (Della Porta 2012a, p.33). Political-economic legitimation crises also transform interpretive frameworks of meaning, "as people withdraw 
This is a pre-print versión Please do not cite. To cite this paper please refer to the published version available here:

https://www.tandfonline.com/doi/abs/10.1080/14742837.2016.1256193 commitment to the social order -creating spaces for alternative

views and understandings"(Langman, 2013, p. 159).

Countering the effects of decline in legitimacy of representative democracy are the mechanisms that reproduce what Badiou (2005), Mouffe (2005), Rancière (2004) and Žižek (2000) have referred to as the "post-political". In the post-political sphere, representative democracy is closely tied to liberal economy, and is mobilized as a means of restricting or foreclosing public debate about the social and economic order. "Politics" is reduced to a form of social administration, organized around consensus about neoliberalism and the liberal state. Did the economic crisis and austerity policies then produce a rupture in the post-political consensus? Although mobilization is partly a response to the crisis, grievances on their own will not lead to mobilization (Langman, 2013; Oliver, 1989). What then causes discontent levels to change significantly? And how was this discontent framed by collective actors in the European wave of mobilization?

In European countries affected by the crisis and austerity policies, mass mobilizations against austerity were driven by two main sets of actors: institutional left (e.g. unions, smaller parties) and more autonomous "subterranean" actors. The cleavage between these actors, each of whom has a distinct logic of collective action, is a significant feature of the European social movement landscape (Flesher Fominaya 2007, 2014a; see also Císař and Navrátil, this issue; and Kannellopoulos et.al, this issue). However, in keeping with 
This is a pre-print versión Please do not cite. To cite this paper please refer to the published version available here: https://www.tandfonline.com/doi/abs/10.1080/14742837.2016.1256193 other periods of intense mobilization, alliances across different actors were also forged (Koopmans, 2004; Tarrow, 1998).

Institutional actors played a crucial role in some countries, such as Portugal, where unions initiated protest more effectively than "newer" more autonomous types of actors (Accornero and Pinto, 2015). Trade unions have also played a key role in other national mobilizations (see Accornero and Pinto, 2015, for Portugal; Balbona and Begega, 2016, for Spain; Císař and Navrátil , this issue, for the Czech Republic; della Porta et.al., 2012, for Italy; Kannellopoulos et. al, this issue, for Greece). These forms of protest contributed to the erosion of legitimacy of the specific governments in power at the time, and indeed governments that oversaw austerity policies and labour reforms paid the price at elections (see Hayes, this issue).

The autonomous actors were those involved primarily driving the movements of the squares and related initiatives, who in the wake of the financial crisis and the devastation wrought by austerity policies, attempted to translate the decline in trust, satisfaction and legitimacy of representative democracy into a legitimation crisis, and to break the restrictions and apathy of the post-political. In the face of a crisis of political representation, these activists/citizens did not ask for less politics, but more politics. These autonomous activists broadened the resistance to austerity into a debate about the nature and meaning of democracy. Activists in Spain, Greece and in other squares demanded a reclaiming of democracy and its institutions, they appealed to the rights enshrined in the constitution, to national sovereignty and 
This is a pre-print versión Please do not cite. To cite this paper please refer to the published version available here: https://www.tandfonline.com/doi/abs/10.1080/14742837.2016.1256193 governments that respond to citizen needs (Benski et.al, 2013;

Flesher Fominaya, 2014a, 2015a; Gerbaudo, this issue; Oikonomakis and Roos, 2016). This is what Spanish activists meant by the slogan "we are not anti-system, the system is anti-us". And this is why the term anti-politics, sometimes applied to these mobilizations, is spectacularly misleading. In European countries affected by the crisis, when activists manage to frame the democratic deficit as responsible for the crisis and its effects, this intertwining of these crises provide a powerful impetus for mobilization. (della Porta, 2012b, 2015; Flesher Fominaya 2014a, 2015a and b; Shihade, Flesher Fominaya and Cox, 2012).

Research shows that activists across Europe perceived the crisis as a political crisis, not just an austerity crisis, and that their mobilizations despite not necessarily being larger or more connected to each other than those during the GJM, managed to have greater resonance in mainstream public opinion (Kaldor and Selchow, 2013). Contesting "really existing democracy" has also produced more visible results than resisting austerity. Although austerity policies are still in place across Europe, the demands for real democracy have paradoxically delegitimized representative democracy but also relegitimized it through the attempts to reclaim democratic institutions for the citizens. I am arguing then, for the fruitfulness of adopting a lens that sees these post-2008 European mobilizations not only as "anti-austerity" movements but crucially as pro-democracy movements (Flesher Fominaya 2014a, 2015a). Without the global financial crisis, the general decline in trust and satisfaction with democracy (a long term trend in Europe in any event) would not 
This is a pre-print versión Please do not cite. To cite this paper please refer to the published version available here: https://www.tandfonline.com/doi/abs/10.1080/14742837.2016.1256193 have been effectively channelled by core activists into counter-

hegemonic narratives about the crises (financial and democratic). The presence or absence of a strong pro-democracy narrative that connects actors across sectorial and organizational differences, could help explain why we find anti-austerity mobilization even in places where there was little austerity (Germany) and conversely its weak presence where there was "strong" austerity (Ireland).

Translating grievances into collective resistance requires activating networks of actors willing and able to make effective use of the political and economic opportunities opened up by these "twin" crises. Here the interplay between the particular strength and density of local and national activist networks (and their human, material, cultural and ideological resources) and public perceptions of the crises and who is responsible for them is important. Public perception is itself partly affected by the mobilizations of critical social movements (e.g. disclosing and disseminating corruption scandals and counterhegemonic narratives or slogans such as crisis/swindle), but also countered by viewpoints disseminated by mass media that support dominant narratives, (e.g. austerity is inevitable, banks are too big too fail, and so on). At the same time, transnational diffusion processes also significantly influence and contribute to mobilization processes (and here national and transnational activist/critical citizen networks played a key role through whistleblowing and critical alternative media, and the influence of groups such as Anonymous and Wikileaks). 
This is a pre-print versión Please do not cite. To cite this paper please refer to the

Formatted: English (UK) published version available here:

https://www.tandfonline.com/doi/abs/10.1080/14742837.2016.1256193

Recognizing the synergistic effects of these crises we can argue that

these mobilizations can be seen as counter-hegemonic when they

seek to rupture the ("post-political") consensus around the neoliberal order underpinning state and representative democracy. Counterhegemonic mobilizations encompass not just a critique of specific policies and material demands, but also seek to expose the connections between the political (and not just abstract economic) causes of the crisis; the political choices made in adopting austerity policies (which despite the constraints imposed by supranational dictates, are still choices, and not an inevitable response to abstract economic considerations); and the material outcomes of those austerity policies. The penetration and resonance of counterhegemonic narratives varied across specific national contexts, but their replication across sites arguably created a multiplier effect that at the very least opened up the possibility for imagining new forms of democratic engagement and alternatives to austerity.

\section{From the Global Justice Movement to Anti-}

\section{Austerity/Pro-Democracy Movements}

Recognizing the importance of the crisis of legitimacy of representative democracy, located primarily (but not exclusively) within the framework of the nation state, and its close relation to the financial crisis, also helps explain the most significant changes and continuities from the previous wave of protest, the GJM.

Discontinuities: From the transnational to the national and from antineoliberalism to anti-austerity

In both the GJM and the wave of anti-austerity mobilizations in 
This is a pre-print versión Please do not cite. To cite this paper please refer to the published version available here:

https://www.tandfonline.com/doi/abs/10.1080/14742837.2016.1256193

Europe, activists were contesting the global socio-economic order.

The clearest difference between the GJM and the current wave of protests in Europe is the effect of the financial crisis and austerity measures on the sites and target of activism. If during the GJM activists in wealthy countries were often mobilizing on behalf of less fortunate others often "far away", in the post-crisis scenario those injustices were brought home and made visible, whether through witnessing increased homelessness and neighbors searching through the garbage for food, experiencing unemployment or benefit cuts, visiting food banks for the first time, or reading about evictionrelated suicides. People were no longer mobilizing on behalf of an often abstract "other" but on behalf of themselves, their families, and their fellow citizens.

The most notable shift in targets is from supranational and intergovernmental institutions, such as the World Bank and the IMF, and abstract ${ }^{\mathrm{ii}}$ targets such as "global capitalism" during the GJM, to very clear and specific targets at the national level: political and financial oligarchies. It is not that the EU and the Troika are not also blamed for the crisis and austerity, but the nation state is much more central as a stage and focus of collective action (Flesher Fominaya, 2014a). "Anti-neoliberalism" (a systemic critique) becomes "antiausterity" (a critique of specific policies).

The centrality of the nation-state is manifest in collective action in a number of ways: discursively, tactically, and spatially. Where the master narratives of the GJM often bypassed the state, considering it to be an actor and target of lesser importance than supra or international actors, in the current wave, activists are reclaiming state 
This is a pre-print versión Please do not cite. To cite this paper please refer to the published version available here: https://www.tandfonline.com/doi/abs/10.1080/14742837.2016.1256193 democracy, appealing to their respective constitutional guarantees, and bringing narratives about "the people", "the nation" (long the discursive realm of the "right") back in (see also Gerbaudo, this issue). Protesters in countries that witnessed strong mobilizations, such as Spain and Greece, are explicitly making visible the overlap between the economic and political classes, laying bare the neoliberal nature of the state (Harvey, 2011) and refusing to accept narratives that lay the responsibility for the crisis and austerity to global economic processes beyond state control.

Where the most emblematic and visible forms of GJM activism in Europe were transnationally organized counter-summit protests and International and European Social Forums contesting the policies of transnational or multilateral actors (e.g. EU Presidency meetings and international summits), the majority of mobilizations in the current wave took place in the centres of major cities, often at locations emblematic of nation- state power and representation (e.g. parliament).

During the GJM master slogans such as "Another Europe is Possible" called for an alternative EU/ imagined Europe, but during this post/crisis scenario "Europe" becomes less visible (Kaldor and Selchow, 2013). However, there were significant anti-Troika mobilizations in a number of countries, including the "Fuck the Troika" protests in Portugal (15 September 2012, 2 March 2013), numerous general strikes and mass protests directly related to EU/Troika actions from May 2010 to present in Greece, mass protests in Romania against a 20 billion euro EU/IMF rescue package and austerity measures which caused the government to resign in 
This is a pre-print versión Please do not cite. To cite this paper please refer to the published version available here: https://www.tandfonline.com/doi/abs/10.1080/14742837.2016.1256193 2012, and anti-austerity protests in Ireland (10 February 2013). The anti-Troika protests in Greece and Portugal were nevertheless embedded in narratives and symbols appealing to shared national history (Baumgarten, this issue; Sergi and Vogiatzoglou, 2013).

The reclaiming of the state forms part of what I have called the 'democratic turn' (Flesher Fominaya, 2015a) and represents a key departure for autonomous activists in Europe, traditionally key actors in articulating a rejection of global capitalism, who shifted master narratives from a refusal to engage with the state to clear demands for its renewal and accountability (Flesher Fominaya 2010, 2015a). This shift is also noted by Gerbaudo (this issue) who argues that "anti-austerity movements put forward an anti-oligarchic view of citizenship", and in so doing depart from the "anti-statism of autonomous movements." I argue that, in Spain at least, autonomous movements themselves have evolved to embrace and re-appropriate this notion of citizenship, which reflects longstanding autonomous desires to break with the activist ghetto and reach out to "ordinary citizens", but not without important tensions (Flesher Fominaya 2015a). Císař and Navrátil (this issue) also note this shift from the global/transnational to the national focus of protest in the Czech Republic. The shift to the nation-state also explains the different level of collective identities mobilized: in the GJM activists in diverse sites felt part of a global movement, in this global wave nationally and locally rooted movements are connected loosely transnationally, but do not form a transnational global movement (Flesher Fominaya, 2014a). 
This is a pre-print versión Please do not cite. To cite this paper please refer to the published version available here: https://www.tandfonline.com/doi/abs/10.1080/14742837.2016.1256193

Despite earlier research (not limited to the GJM) highlighting a low degree of "Europeanization" of protest overall relative to domestic targets and actors (Imig and Tarrow, 2000), this shift to the nationstate is somewhat surprising. Given the significant role of the Troika in the bail-outs, debt renegotiations and austerity policies of those countries hardest hit, we might expect the degree of Europeanization of protest to increase in the wake of the crisis. Using protest claim analysis Bourne and Chatzopoulou (2015) show that in fact the majority of protest targets, issues, participants and identities in Greece and Spain are domestic. Yet despite similar levels of protest over a similar period, there is significant variation between the two cases. Whereas the largest number of events were characterized as non-Europeanized (all dimensions measured were domestic), "in Greece many more events exhibited at least one dimension of Europeanization (63\%) than the number of those that exhibited no Europeanization at all (37\%). In other words, Europeanization is significant in Greece, but not in Spain (Bourne and Chatzopoulou, 2015:51). Also striking is that targets in Greece were categorized as domestic, European and transnational simultaneously $28 \%$ of the time, whereas in Spain this was the case only $2 \%$ of the time.

Likewise Pianta and Gerbaudo (2015, p.31) find both anti-austerity movements and institutional actors such as unions focused primarily on national targets, despite the fact that European institutions had "a pivotal role in dictating austerity policies on the continent." There is a lower degree of transnational coordination between the two waves as well (Della Porta, 2012b; Kaldor and Selchow, 2013).
Formatted: English (UK)

Formatted: Font: +Body (Cambria), 14 pt

Deleted: that "that anti-austerity movements, as well as more institutional forces like European trade unions, have fallen short from making European institutions and policies the main target of their campaigns, despite the fact that they had a pivotal role in dictating austerity policies on the continent" focusing primarily on national targets.

Formatted: Font: Irish 
This shift from the transnational to the national as an arena of struggle, however, does not describe the totality of mobilizations during this wave. Notable exceptions are the transnational and panEuropean initiatives, "For a European Spring" (Corporate Europe Observatory, 2013), Alter Summit (Alter Summit EU, 2013) and Blockupy ((Blockupy, 2016), which echo the organizational forms and language of the GJM, but now with a specific focus on austerity and a greater critique of the loss of national sovereignty. This more institutional left orientation is also reflected in the important role trade unions play in these trans-European initiatives, and the continuation of some actors, such as Attac. Unions also mobilized transnationally in the historic European transnational general strike action (14 $4^{\text {th }}$ November 2012) under the slogan "For Jobs and Solidarity in Europe. No to Austerity", which resulted in general strikes in Spain, Portugal, Greece, Italy, Cyprus, Malta, Slovenia and Lithuania, and general strikes and sectorial strikes in France and French speaking Belgium.

In their work on transnational mobilization and critical Europeanism, Chatzopoulou and Bourne (2016) show that Alter-Summit, Blockupy and the European Federation of Trade Unions all share a common interest in promotion equality, anti-austerity, solidarity, democracy and social justice, and all critique the democratic deficits of the EU. As transnational social movements they are attempting to combat the "high national fragmentation and [...] incapacity to construct a coordinated campaign at the continental level, commensurate to the 
This is a pre-print versión Please do not cite. To cite this paper please refer to the published version available here:

https://www.tandfonline.com/doi/abs/10.1080/14742837.2016.1256193 governance structures directing austerity policies (Pianta and

Gerbaudo, 2015).

In European anti-austerity protests, therefore, albeit to different degrees across cases, we see a linking of the notion of ineffective, insufficient or deficient democracy and the negative effects of neoliberal global capitalism. The financial crisis is explicitly linked to a crisis of democracy, and, in a significant shift from the GJM the political responsibility for the crisis is attributed not just to international or supranational organizations (such as the ECB, the IMF or the EU Commission), but to national political governments. Additionally appeals to the notion of "citizen" as political subject (as opposed to activists), and the reclaiming of democracy and the nation state (including its institutions and constitutional rights) and appeals to shared national symbols, history and memory move centre stage in the European post-crisis wave of contention.

\section{Continuities: The importance of movement genealogies}

Although I have argued for the current period to be seen as a distinct wave of contention from that of the GJM, there is also clear continuity of actors, social movements, activist networks, master frames, ideological influences and participatory repertoires of deliberation from the GJM to the current wave (see e.g. Fernández-Savater and Flesher Fominaya, this issue; Flesher Fominaya, 2014a, 2015a; Maecklelbergh, 2012; Romanos, 2013; Zamponi and Daphi, 2014; Zamponi and Fernández, this issue ). 
This is a pre-print versión Please do not cite. To cite this paper please refer to the published version available here:

https://www.tandfonline.com/doi/abs/10.1080/14742837.2016.1256193

Indeed, one key problem with thinking in terms of waves or cycles is

that the periods of low activism or latency between waves is often

overlooked, yet has crucial implications for understanding visible

episodes of contention. Baumgarten (2016) (Portugal), Flesher

Fominaya (2015) (Spain), and Zamponi and Fernández (2016) (Italy,

Spain), all highlight the importance of periods of low mobilization in

the development of cultural practices and interpretive frameworks

that later become visible during anti-austerity protest. Paying

attention to continuities helps counter the impression that new

waves of protests "come from nowhere", or are totally new,

unprecedented and spontaneous. Paying attention to the effects of

earlier waves and the particular nature of abeyance periods within

countries can also help explain variation across cases that focusing

on grievances cannot. The variation in strength and type of

mobilization in the countries most affected by the global crisis and

austerity policies show that, legitimate calls for greater attention to

the importance of economic grievances notwithstanding, we cannot

explain the timing, emergence or strength of mobilizations based on

levels of economic impact of the crisis or the nature of austerity

policies.

Pre-existing local and national mobilizations and experiences may explain variation in the nature, strength and impact of mobilizations in ways that, as indicated above, the strength of direct effects of crisis cannot (Flesher Fominaya 2014a, 2015a, Kannellopoulos et. al, this issue, Zamponi and Fernández, this issue). The ability of activists to generate and sustain the occupations is affected strongly by preexisting social movement networks that have the resources 
This is a pre-print versión Please do not cite. To cite this paper please refer to the published version available here: https://www.tandfonline.com/doi/abs/10.1080/14742837.2016.1256193 (material, human, cultural and ideological) to take advantage of the national and transnational socio-political-economic opportunity structures provided by the post-crisis scenario, including mobilizations elsewhere. These findings require a critical reexamination of "spontaneity theses" across cases.

In Italy, Spain, Greece, Ireland, and Portugal, precursor movements (or their absence) made an important difference to mobilization forms, repertoires, alliances and resources mobilized, and what happened once the occupations were over. As Zamponi and Fernández (this issue) show, student movements in Italy and Spain played key roles in influencing the respective anti-austerity mobilizations and discourse in those countries, transforming "the anti-neoliberal discourse" of the GJM into "an anti-austerity discourse". In Europe, the movements of the squares were often initially youth-led (later encompassing wider sectors of the population). Not only were youth mobilizing around their precariousness in the face of austerity cuts to education, housing and soaring youth unemployment, post-crisis, they had already effectively mobilized around precariousness during and since the GJM, introducing the concept and issue of labour precariousness into dominant and institutionalized discourse (della Porta, 2015; Flesher Fominaya, 2014a; Mattoni, 2016; Zamponi, 2012). Those discursive resources and organizational practices then prepared the ground for the renewed protests in the wake of the crisis. Attention to discursive and cultural processes helps us illuminate how grievances are transformed, articulated and mobilized. Cultural repertoires from the GJM were mobilized across different European anti-austerity 
This is a pre-print versión Please do not cite. To cite this paper please refer to the Formatted: English (UK) published version available here: https://www.tandfonline.com/doi/abs/10.1080/14742837.2016.1256193 mobilizations, from the more institutional left approaches adopted in the transnational critical Europeanist protests to the more prefigurative methods used in the movements of the squares (Flesher Fominaya, 2015a; Maeckelbergh,2012; Zamponi and Daphi, 2014).

Whether or not activists could draw on established movement cultures, networks and repertoires also influenced their ability to adopt the occupy style tactics effectively. While the tactic itself is easily replicated (hence its quick diffusion around the world), once occupied, some camps struggled with horizontal assembly style decision making, a process that requires strong protocols, reflexivity and experience to work effectively and to guard against power imbalances, unsatisfactory decision making and other associated potential problems. My comparative research on Spain and Ireland $\mathrm{d}^{\mathrm{iii}}$ suggests that the presence of experienced activists was crucial. Hence activists in Madrid and Barcelona drew on long-standing autonomous practices in and beyond the GJM, to organize their assemblies (with facilitators, moderators, rules of engagement, etc.) whereas activists in Dublin struggled to establish shared codes of practice that could integrate participants effectively. In the absence of a strong core of experienced activists integrated into a shared network they faced more difficulties in their ability to implement horizontal assembly practices.

Pre-existing networks and urban spaces of resistance also made a difference in what happened after the camps were lifted. If Madrid's "Indignados" could take the decision to "go back to the neighborhoods" it was because they had somewhere to go (e.g. 
This is a pre-print versión Please do not cite. To cite this paper please refer to the published version available here:

https://www.tandfonline.com/doi/abs/10.1080/14742837.2016.1256193 squatted social centres, neighbourhood association locales), activists in Dublin hoping to continue to build on the connection made in Occupy Dame Street struggled with a dearth of available meeting spaces (and their occupation dwindled until it was unsustainable).

The implications of this for social movement scholarship is that we need to pay more attention to movement genealogies, including the configuration, spaces and resources of pre-existing networks, and to the role of movement cultures and discursive processes in mobilization, avoiding the myopia of the present and the myopia of the visible that Melucci (1994) alerted us to (see also Flesher Fominaya, 2015a). At the same time, we should not ignore the importance of political and economic contextual factors, including grievances, in shaping anti-austerity resistance (Císař and Navrátil, this issue). Crucial too are the interpretive systems of meaning that motivate collective action. As I argued above, for movements with a counter-hegemonic orientation, democracy was a central interpretive framework for anti-austerity protest, manifested most emblematically in "the movements of the squares". I turn to this now.

\section{Democracy Central}

\section{Democracy as interpretive framework for austerity}

Political-economic context and pre-existing movement resources provide important tools for understanding episodes of mobilization in national contexts. But it is also crucial to understand that interpretive systems of meaning that motivate collective social action, while in many ways rooted in national political cultures, can

Deleted: and interpretive schema, 
This is a pre-print versión Please do not cite. To cite this paper please refer to the published version available here:

https://www.tandfonline.com/doi/abs/10.1080/14742837.2016.1256193 and do cross national boundaries. Demands for greater democracy

form a central shared theme across a wide range of protest sites and forms of protest (Dekker and Feenstra, 2015), within and beyond Europe. Drawing on research conducted by seven field teams in Germany, Italy, Spain, Hungary, London and two Trans-European teams, Kaldor and Selchow, (2013, p.78) show that what they call "subterranean actors"iv across countries "perceive the crisis as a political crisis rather than a reaction to austerity. [This] is just as much a characteristic of Germany, where there are few austerity policies, as other countries." The resonance of the mobilizations across mainstream public opinion was striking. Their strongest finding is that extensive frustration and deep disappointment with current politics is what connects different types of protests, actions, campaigns and initiatives, despite little connection between cases. The second key finding was a shared deep concern with democracy and the need for its collective re-imagining, and from all the case studies the centrality of "the subjective experience of participating in politics in a new way" (2013, p.88). The strong connection between activists' anti-austerity and critical pro-democracy interpretive frames has been highlighted in numerous other studies (Benski et. al, 2013; Flesher Fominaya, 2015a, 2016; Glasius and Pleyers, 2013; Oikonomakis and Roos, 2016; Powell, 2015; Sotirakopoulos and Sotiropoulos, 2013).

The extent to which strong connections were made between the erosion of democracy and austerity, and to which that was effectively mobilized to resonate among the population might help explain variations in anti-austerity responses across different national 
This is a pre-print versión Please do not cite. To cite this paper please refer to the published version available here: https://www.tandfonline.com/doi/abs/10.1080/14742837.2016.1256193 contexts. Císař and Navrátil (this issue) find that in the Czech

Republic, for example, the "western based quest of anti-austerity movements for an alternative democracy" was not found beyond a moderate call for greater transparency and minimizing the scope for corruption in the outsourcing of public services. Nor was a deep critique of neoliberalism present. Nevertheless, fixing the malfunctioning state was a central demand.

My researchv shows that in Spain, "democracy" forms an overarching master frame that connects diverse anti-austerity actors across issues and organizational forms, whereas in Ireland, where there was a much weaker collective resistance to austerity, although there are critiques of a democratic deficit from some actors, no such overarching narrative can be found. This might suggest that a shared master narrative about democracy (as a system/idea) and not simply levels of economic grievances or hardship or a shared rejection of austerity policies (as a set of specific issues) help explain differences in levels of mobilization (although not independently of other explanatory factors). As Stavrides (in Fernández-Savater and Flesher Fominaya, this issue) argues, what connects these events across cases is that they "were open manifestations of a growing delegitimization of the corresponding regimes". This de-legitimization spurred the confrontation of direct or participatory and representative models of democracy, a contest that emerged even when initiated in the context of strongly material issues, such as the housing crisis in Spain (Flesher Fominaya, 2015b). In the task of developing and disseminating a strong narrative that tied austerity 
This is a pre-print versión Please do not cite. To cite this paper please refer to the published version available here: https://www.tandfonline.com/doi/abs/10.1080/14742837.2016.1256193 policies to democratic deficits the occupation camps-fuelled by autonomous rather than institutional left actors-played a central role.

\section{The Occupations of the Squares: Democracy in Acampada Solvi}

Within the wide range of anti-austerity protests across Europe, the camps or "occupations" were crucial mechanisms of the development and diffusion of a counterhegemonic narrative of the crisis. Narratives are a common set of stories told in the public sphere around a common conceptual framework (Polletta, 2006). If in the "post-political" sphere alternative and dissenting visions of society remain hidden, in the movements of the squares they become visible and open to new actors and new influences. If in the postpolitical realm the retrenchment of representative democracy in the liberal state is built around consensus and a lack of critical alternatives that is deeply de-politicizing, the camps serve to provide a public space of re-politicization. Through their inclusive and elastic entry requirements (anyone can be in the square), camps enabled people without an overarching interpretive framework of the crisis, austerity or democracy to be integrated into a collective process of re-imagining and critique.

Acampada Sol, arguably the most influential square in Europe, provides an illustrative example of how the central conceptual framework of democracy manifested through the diverse aspects of the camp. Although an exemplary case, in terms of its influence, strength, and the central coherence of democracy as an interpretive framework, Acampada Sol illustrates important features manifested in camps elsewhere. Commencing in Madrid the night/morning 
This is a pre-print versión Please do not cite. To cite this paper please refer to the published version available here: https://www.tandfonline.com/doi/abs/10.1080/14742837.2016.1256193 following the original 15-M (15 May, 2011) protest for "Real

Democracy Now!" the camp remained in Madrid's central Puerta del

Sol for 28 days, surviving eviction attempts, and finally taking the collective decision to "decamp" with slogans such as "We are not leaving, we are expanding" and "We are moving to your consciousness". The critique of really existing democracy and the development of alternative democratic imaginaries manifested in Acampada Sol in seven key ways, serving as a heterotopic crucible for the emergence and development of what became the 15-M movement.

First, in the face of increased unemployment and social inequalities, and a rigid bureaucratic regime unresponsive to the needs of the people, activists expanded the frame and scope of who could be an agent of change, identifying themselves and appealing to others as “citizens” and “ordinary people” (Flesher Fominaya, 2015a).

Second, the central demand of the camp echoed the original 15-M protest call for "Real Democracy now!". During the camp over 15,000 proposals to improve democracy were gathered. In the face of a devastating crisis, the camp allowed many people to shift from a feeling of "what can I do?" despair to a feeling of "what can we do?" hope and indignation.

Third, the camp was laboratory of civil disobedience, which, in an electoral context, directly engaged with existing mechanisms of representation, and agents of the state. The day before the elections in Spain is called the "day of reflection" during which campaign 
This is a pre-print versión Please do not cite. To cite this paper please refer to the published version available here: https://www.tandfonline.com/doi/abs/10.1080/14742837.2016.1256193 activity is suspended. Despite not campaigning for any party, the camp was ordered to be evicted, but the general assembly decided to deliberately violate the day of reflexion prohibition with a "grito mudo" (a silent scream where all those gathered raised their hands in silence for a minute), contesting the idea that political participation meant voting every four years. This ultimately forced political elites who initially tried to simply ignore the protests to engage with the challenges to their legitimacy. Mass actions of civil disobedience also forged strong solidarity between activists, an emerging collective identity as a new political subject (what would later be known as "15-M"), and the strong emotional impact that many participants recall years later (e.g. "I had goose-bumps", "It felt euphoric, like anything was possible").

Fourth, the camp pre-figuratively experimented with participatory processes organized around a commitment to non- hierarchy (horizontalism) and inclusivity and the creation of a res publica. Prefigurative action reflecting this desire to rethink and re-imagine democracy. characterized occupied squares in other sites too, through debate over the meaning of democracy and experimentation with new forms of life in common, unmediated by institutions (see Fernández-Savater and Flesher Fominaya, this issue).

Fifth, Acampada Sol and other occupied squares, brought people who would not ordinarily engage with each other in urban settings, across age, class, and ethnic divides, defying social conventions and providing a new model for civil-social interaction. 
This is a pre-print versión Please do not cite. To cite this paper please refer to the Formatted: English (UK) published version available here: https://www.tandfonline.com/doi/abs/10.1080/14742837.2016.1256193 Sixth, democracy was not limited to the rational discursive sphere (in the Habermasian sense) of the general assemblies. The need to organize the material aspects of the camp's life in common provided numerous opportunities to politicize the normally mundane, from rethinking child care and feeding people (e.g. bringing feminist and environmental issues to the fore), to addressing interactions with police (e.g. stimulating a rethinking of the state's legitimate use of violence). If austerity policies neglect people's material needs, placing capital before life, as some activists have so succintly put it, the camp inverted that formula, putting life before capital. The camp provided a model for meeting people's material needs in a way that respects them, engages them, and empowers them, drawing on feminism and on autonomous, pro-commons, DiY and anti-charity /anti-assistance-based models (asistencialismo).

Finally and crucially, Acampada Sol brought diverse pre-existing networks of activists together around a shared "problematic" of democracy, allowing them to allowed them to cross-contaminate through synergy, reciprocity and contestation, lending specific substantive content to the "new" democratic imaginary. As Tejerina and Perugorría (2012, p. 95) note of the camp "public discourse...is no longer inspired by a stiff and self-contained system of ideas focusing on material welfare, but by an open and flowing amalgam of ideological postulates increasingly focused on the deepening of democracy in daily life and everyday practices". Particularly noteworthy are the reciprocal influences between autonomous, feminist, and hacker ethics. Although each camp had its own unique characteristics and evolution, many of these characteristics were 
This is a pre-print versión Please do not cite. To cite this paper please refer to the published version available here: https://www.tandfonline.com/doi/abs/10.1080/14742837.2016.1256193 shared across diverse occupation sites (see e.g. Pickerill and Krinsky, 2012; and Martín Rojo, 2016). vii

\section{Beyond the national: Transmission, diffusion, contagion and resonance in the "movements of the squares"}

Although national contexts are crucial in explaining variations in protest across Europe, this wave is also characterized by a high degree of transnational diffusion. Europe can be seen as a space of contagion for social movements (Scholl, 2013). Here again, the most emblematic, influential and widespread forms of "anti-austerity" protest in Europe, were the "movements of the squares" or the Occupy style movements. The centrality of the demands for "real democracy" form a central narrative that connects not only the different movements of the squares in Europe but also connects them to the wider global wave of protest. Yet, as the example of Spain's 15M shows, transnational diffusion processes are circuitous, complex, and reciprocal rather than linear as transmitter-adopter models would suggest.

Spain's 15-M movement and particularly the experiences of Acamapada Sol was clearly a model for European anti-austerity movements with far reaching influence (Accornero and Pinto, 2015, Romanos, 2015). Spain's 15-M itself emerged partly in response to the events in North Africa and particularly Tahrir square in early 2011, whose influence was felt in Europe far beyond Spain (see, e.g. Baumgarten 2013; Benski et. al., 2013; Roos and Oikonomakis, 2015; 
This is a pre-print versión Please do not cite. To cite this paper please refer to the published version available here:

https://www.tandfonline.com/doi/abs/10.1080/14742837.2016.1256193

Sergi and Vogiatzoglou, 2013), but 15-M was also influenced by

Iceland's Saucepan Revolution in 2009, Portugal's Geraçao a Rasca

protests, and other transnational events like Wikileaks

Despite this international influence, the demand for "Real Democracy

Now!" was directed squarely at Spain's national and political elites.

Despite or perhaps because of this targeting of national oligarchies,

the language it developed and the claims made for "Real Democracy

Now!" found resonance across Europe and other parts of the world.

(Accornero and Pinto, 2015; Oikonomakes and Roos, 2016; Sergi and

Vogiatzoglou, 2013). On October 15, 2011, “15-0”, a global day of

action under the slogan "Stop the cuts, rescue the people" inspired by

15-M brought people out on the streets and squares in some 951

cities across 82 countries (della Porta and Mattoni, 2014; Tejerina

and Pergurría, 2012).

Spain's 15-M movement along with activists from the Greek

"Aganaktismenoi" or Indignados viii movement later played a key role in shaping the protests of Occupy Wall Street (Kroll, 2011; Lawrence, 2012; Romanos, 2015). But the OWS protests too drew strongly on local and national political movement traditions, and US political cultural narratives, leading to the "We are the 99\%" formulation that then made its way back to Europe and other countries around the world. ${ }_{4}^{\text {Tx }}$ These routes and the influence of MENA and European

Formatted: English (UK) formulations and experiences are sometimes forgotten, and a certain privileging of Occupy Wall Street (OWS) emerges, such as in Pickerill and Krinsky's (2012, p. 284) early (and problematic) claims that:

Certain choices and tactics and strategies are deeply rooted in 
This is a pre-print versión Please do not cite. To cite this paper please refer to the published version available here:

https://www.tandfonline.com/doi/abs/10.1080/14742837.2016.1256193 the Anglo activist approach and some of this did not easily translate to other countries, such as Italy... Depending on one's starting point Occupy can be perceived as a global movement (inspired by the Arab spring) or as a North American concept which was copied across Europe (particularly in Britain).

These claims overlook the chronological order of the protest events as well as the transnational dimensions of contagion between sites, less documented at their time of writing. As Zamponi and Fernández (this issue) show, OWS was not a major point of reference in Italy relative to other movements, and certainly OWS was strongly influenced by Egypt, Spain and Greece (Kroll, 2011; Lawrence, 2012; Romanos, 2015). OWS in turn had an important influence on the rest of European mobilizations, but primarily in contexts that took the US as an important social movement referent, such as the UK and Ireland, for both linguistic reasons as well as reciprocity between movement communities in these countries ${ }^{\mathrm{x}}$.

Circuitous too was the transmission between Portugal's Geraçao a Rasca, which predated and also influenced Spain's 15-M, but then was remobilized and influenced by the latter movement's strong emergence onto the national and world stage (Accornero and Pinto, 2015; Baumgarten, 2013). Greece had already been experiencing more "traditional" forms of mobilization from April 2010 to April 2011 prior to the emergence of 15-M, including general strikes, clashes with police and protests throughout Greek cities. The shift to the "Indignados" occupy-style movement came from the influence of Arab Spring and Spain's 15-M (Sergi and Vogiatzoglou, 2013). 
This is a pre-print versión Please do not cite. To cite this paper please refer to the published version available here:

https://www.tandfonline.com/doi/abs/10.1080/14742837.2016.1256193

Meanwhile Ireland, despite assuming a 65 Billion Euro Debt to bail

out the banks, and their own Occupy experience in Dublin and other

cities, failed to generate a sustained or mass resistance to austerity.

While Ireland later experienced mass mobilizations around the

"Right to Water", the claims and demands of this movement differ

markedly from the broader demands for democratic regeneration

and an end to austerity policies found in the earlier Occupy

movements around Europe and even the US (a closer point of

reference for Ireland in many ways). Although there is clear

evidence of 15-M activists acting as "brokers" in the run-up to

Occupy Dame Street (Dublin), the strongest point of reference within the camp appears to have been OWS, and not 15-M.

Although witnessing various forms of anti-austerity protest, including numerous strikes and the radical "bossnappings" (Parsons, 2013), France was a "sleeper country" in terms of occupy-style movements, (Chabanet and Royall, 2015) their occupations having relatively little impact until Nuit Debout erupted in Paris 2016. Suddenly, just as activists in Spain thought they were hitting a wall and making little progress on many of their original demands for democratic regeneration, they found Parisian activists singing them Happy Birthday on the $5^{\text {th }}$ anniversary of 15-M (eldiario.es, 2016a), and making reference to their movement as an inspiration (Bautista, 2016). This Parisian experience then influenced renewed occupations in Spain in the Basque country, an area that had had very little mobilization in 2011, when most of the rest of the country was taking to the streets, and global Nuit Debout actions were called for (Bautista, 2016). Here then the Spanish Basque activists were clearly 
This is a pre-print versión Please do not cite. To cite this paper please refer to the published version available here: https://www.tandfonline.com/doi/abs/10.1080/14742837.2016.1256193 referencing their French counterparts, and adopting their name, and not that of $15-\mathrm{M}$.

This tracing of Spain's 15-M movement's influence from and diffusion to other occupy-style movements shows that the transmission processes between movements are very difficult to predict and do not follow a linear chronological pattern from one country to the next but are made up of complex reciprocal flows. Transmission took place directly and indirectly, sometimes face-to-face, sometimes mediated in myriad ways. Activists in Dublin told me how they watched OWS live-streams to get a better sense of how to go about their own assemblies, a sort of remote learning facilitated by the digital technology practices that helped disseminate movement practices and frames from one context to the other. As is clear from the testimonies of activists in Turkey, Portugal, Spain, Greece, Egypt and the US in the roundtable discussion on "Life After the Squares" in this issue "almost all cases occupied squares referred to each other and recognized shared characteristics" (Stavrides in FernándezSavater and Flesher Fominaya, this issue). As Oikonomakis and Roos (2016) argue we need to dispense with linear understandings of diffusion and instead recognize the complexity of patterns of "resonance" between protest movements.

\section{Consequences}

Koopmans (2004) and Tarrow (1998) argue that repression and institutionalization are two common outcomes of waves of protest that also contribute to "contraction" or a decrease in mobilization (along with other factors, such as protest fatigue). Within Europe we 
This is a pre-print versión Please do not cite. To cite this paper please refer to the published version available here: https://www.tandfonline.com/doi/abs/10.1080/14742837.2016.1256193 have seen evidence of these effects in some cases. In Spain, the strong challenge to "democracy as usual" is revealed in the two most visible and unintended consequences of the mobilizations: the legal reforms enacted in the wake of the protests to restrict the right to protest, and the institutionalization of the movements in the form of new hybrid-parties, such as Podemos and the municipal movements. Although an exemplary case, the consequences in the Spanish case offer insights into processes also underway elsewhere.

\section{Legal repression and the silencing of dissent}

Strength of mobilization did not have a direct effect on receptivity to citizen demands from political elites, but did prompt an unintended consequence in the form of increased repression and an alarming closing of political space for dissent, a trend that has spread across Europe, facilitated discursively in some cases, such as France and Belgium, by terrorist attacks that provide an excuse to also shut down peaceful and legitimate forms of protest and resistance. From the gag law in Spain to the suspension of anti-climate change protests in France, to the curtailing of internet freedom and freedom of expression in Turkey, governments across Europe are tailoring their legislation to silence dissent (Çigdem in Fernández-Savater and Flesher Fominaya, this issue; Freedom House, 2016a and b) .

Spain's reform of the penal code and the Law for the Protection of Citizen Security, known as the "Gag Law" (Ley Mordaza) was a clear response to anti-austerity and pro-democracy protest. The clear causal link between the high levels of citizen mobilization and the 
This is a pre-print versión Please do not cite. To cite this paper please refer to the published version available here:

https://www.tandfonline.com/doi/abs/10.1080/14742837.2016.1256193 new legal restrictions has been made by International Organizations, including the UN Human Rights Office of the High Commissioner (2015). One such tactic is the increasing use of fines to punish and dissuade peaceful protest. Under the existing Law for the Protection of Citizen Security (1992), fines range from €100 to €1001 for lesser infractions and up to $€ 600,000$ for very serious infractions. Refusing to dissolve a protest, for example, is a 'serious infraction' (Amnesty International, 2014). The use of administrative fines is increasing, and in a recent report, the Commissioner for Human Rights for the Council of Europe (2013, p.18) expressed concern, considering it to constitute a violation of freedom of expression and association.

Clearly the possibility of incurring huge and disproportionate fines is intended to dissuade protest and silence the voices of citizens outraged by, the privatization of public services, the imposition of punitive austerity measures and corruption scandals, among other grievances.

Amnesty International (2014, p.24) points out that this generates a "grotesque situation" where those most affected by the crisis are unable to exercise their democratic right to protest due to the inability to pay the fines they will get for doing so. Legal Sol, who offer support to 15-M activists in Madrid, registered 1,010 fines totalling over 320,000 Euros between May 2011 and November 2013. However, the increased and often arbitrary application of existing law was not sufficiently restrictive, according to the Popular Party (Amnesty International, 2014), hence the reform of the penal code and modification of the Law of Protection of Citizen Security (Flesher Fominaya, 2014b). These legal reforms in Spain are also a 
This is a pre-print versión Please do not cite. To cite this paper please refer to the published version available here:

https://www.tandfonline.com/doi/abs/10.1080/14742837.2016.1256193 response to activists who have taken on cases of high level fraud and corruption (such as 15mpaRato), and go hand-in-hand with other mechanisms of counter-resistance such as the political use of the judiciary system, another crucial area of concern (e.g, see Escolar, 2016) as well as political manipulation of public news broadcasting (Eldiario.es, 2016b). Members of the Platform for those Affected by Mortgages (PAH), who protest, inter alia, at having to keep paying their mortgage debt, despite losing their homes to foreclosure, have accumulated tens of thousands of Euros in fines (PAH, 2016) and journalists documented 40.000 fines to members of the press in seven months alone in 2015 (Reporteros sin Fronteras, 2016). There are numerous cases of imprisonment for protests and on-going trials (too numerous to list here, but see Legal Sol's website https://legal15m.wordpress.com/).

Legal restrictions and criminal and civic costs associated with peaceful protest, therefore, form a crucial part of political opportunity structures, as we would expect. But what we also see is that mass mobilization also has increased restrictions as an unintended consequence of pro-democracy mobilization, leading to fewer rather than greater democratic rights.

Given the key role of the internet and digital media in disseminating counter-hegemonic narratives and as an organizing platform for protest, it is no wonder that internet freedoms are also being curtailed and online expression is being criminalized. As with resisting Gag Laws and other threats to freedom of protest and expression, resisting curtailments to democratic freedoms online 
This is a pre-print versión Please do not cite. To cite this paper please refer to the published version available here: https://www.tandfonline.com/doi/abs/10.1080/14742837.2016.1256193 depends on the existence of a motivated network of collective actors who actively advocate for the political use of the internet and establish channels for effective political communication online. These include encrypted whistleblowing facilities that connect journalists, lawyers and whistleblowers (such as Wikileaks, or Spain's Fíltrala or BuzónX); critical alternative news outlets that inspire confidence through journalistic rigour and reputation; and effective social movement and citizen journalism networks.

\section{Reconfiguration of the political landscape}

These mobilizations have also had an impact on the electoral sphere, again to greatly different degrees: in Spain, the movement has reconfigured the political landscape, and led to the creation of new parties such as Podemos and new municipal platforms, putting an end to bi-partisan alternating of power (Atentas, 2016). In Greece, a pre-existing party (Syriza) initially sceptical of the participants in Syntagma, benefitted from the increased mobilizations to become the governing party (see Kannellopoulos et. al., this issue; and Stavrides in Fernández-Savater and Flesher Fominaya, this issue). In both cases, their relation to grassroots movements has been problematic and contested (Flesher Fominaya, 2014c; Stavrides in FernándezSavater and Flesher Fominaya, this issue).

Iceland has had a remarkable series of changes since their Saucepan Revolution, first ousting the austerity government responsible for the country's bankruptcy only to vote them in again a short time later, (Flesher Fominaya, 2014a) with the direct/liquid democracy Pirate Party's support jumping in the wake of the Panama Paper scandals 
This is a pre-print versión Please do not cite. To cite this paper please refer to the published version available here:

https://www.tandfonline.com/doi/abs/10.1080/14742837.2016.1256193

(Electograph, 2016) but not yet converting public support to strong

parliamentary representation ${ }^{\mathrm{xi}}$. Other countries hoping to convert

popular protest into strong electoral options have been less

successful, although Italy's 5 Stelle movement managed to effectively

channel public sentiment even in the absence of a strong grassroots

movement base, winning important electoral victories (Mosca, 2014).

In other cases, the movements did not lead to the creation of new parties but did galvanize popular support for leaders with an antiausterity agenda: UK Labour's Jeremy Corbyn (and indeed the Bernie Sanders campaign in the US) cannot be understood without factoring in the influence of the occupy movements.

Anti-austerity political representation does not necessarily translate into an overturning of austerity policies. Despite strong mobilization in Greece and a nation overwhelmingly in favour of rejecting the Troika's dictates, the Greek government despite initial resistance, ultimately gave in to the Troika's demands in a negotiation where the power imbalance between players was great. Today Greece’s Syriza government is "absolutely following the policies it condemned before it came to power...the official rhetoric is following the good old tactics of giving new names to old policies and of disguising brutal neoliberalism as opportunities for development and economic growth" (Stavrides in Fernández-Savater and Flesher Fominaya, this issue).

In addition to national hybrid parties, we are seeing movementbased political initiatives take over local administrations in Spain and Italy, calls for increased democratic participation at all levels of 
This is a pre-print versión Please do not cite. To cite this paper please refer to the published version available here: https://www.tandfonline.com/doi/abs/10.1080/14742837.2016.1256193 government, and initiatives such as Plan B, calling for greater transnational coordination across national movement networks in the face of the impossibility of individual states confronting the European Union and the Troika on their own (Plan B, 2016)xii.

\section{Counter-hegemony}

The greatest impact of anti-austerity resistance in the public sphere has been the challenge to until recently hegemonic narratives that justified the crisis and the neoliberal order. One of the crucial features of Spain's 15-M discourse was the framing of a collective identity (a "we") that was elastic, ambiguous, open, and inclusive, constituted around notions of "we the people" and ordinary citizens (Errejón, 2015; Flesher Fominaya, 2015a; Tejerina and Perrugoría, 2012). It is this aspect of the movement's discourse that has led it to be characterized (often pejoratively) as "populist". In contrast to "thick" populism (Jagers and Walgrave, 2007), however, it is not exclusionary. In addition, the movement played a crucial role in defining the "them" against which they mobilized, framed as an unholy alliance of political and economic elites that abused their power for self-interest and against the direct interest of the people, and adding insult to injury, passing on the cost of their "crisis/swindle" to hardworking people. The movement's counterhegemonic (or "anti-systemic" if we adopt the terminology used by political elites) discourse unleashed a public struggle over the meaning of "legitimate democracy" (Flesher Fominaya, 2015b). 
This is a pre-print versión Please do not cite. To cite this paper please refer to the published version available here:

https://www.tandfonline.com/doi/abs/10.1080/14742837.2016.1256193

This us versus them framing was by no means unique to Spain, and

was most effectively encapsulated in the widely circulated OWS

slogan "we are the 99\%". Effective as it is, the narrative of the $99 \%$

against the $1 \%$, also brings it own problems, not least a failure to

recognize the myriad ways power, discrimination and injustice

traverse that $99 \%$ in the form of sexism, racism and classism (Calvo

and López 2015; Flesher Fominaya, 2015c). In Spain, strong feminist

influences and a strong focus on the human, material, consequences

of austerity have been partially successful in counteracting the worst potential consequences of this blind spot. Despite these limitations,

15-M and other anti-austerity movements were successful in

contesting hegemonic narratives that defined the crisis as

unavoidable or the effect of abstract economic forces outwith human

control, and austerity policies as the inevitable result of these same

processes $^{\text {xiii. }}$ These counter-narratives were mobilized in multiple

ways and disseminated through complex media on/offline networks.

Crucially, in the face of widespread human misery, fear and a

declining confidence in representative democracy, these

mobilizations offered an often joyful possibility that change was

possible. As Stavrides (in Fernández-Savater and Flesher Fominaya, this issue) argues:

Delegitimization of power, demythologizing of state violence and the revelation of injustices did not result in the paralyzing view that nothing can be done, that politics stinks, that the powerful are invincible. Squares produced real tangible alternatives both to politics, to the everyday survival tactics and to the existing forms of social organization. And those 
This is a pre-print versión Please do not cite. To cite this paper please refer to the published version available here:

https://www.tandfonline.com/doi/abs/10.1080/14742837.2016.1256193 alternatives are bound to greet new eruptions of collective inventive resistance.

\section{Beyond "politics"}

But impacts cannot and should not be measured solely in such narrow political terms. As the roundtable curated by FernándezSavater and Flesher Fominaya in this issue shows, the occupation experiences have had lasting impacts wherever they have emerged, independently of the "success" or "failure" of the mobilizations. We should expand our intellectual curiosity beyond the State to explore the impacts of these occupations on movement networks, cultural and artistic developments, the emotions and relationships of the participants, the emergence of new forms of media, and nonmovement specific initiatives inspired by the protest experiences such as civil society organizations and economic initiatives.

We also need to recognize that perhaps the most important forms of anti-austerity resistance are not to be found in mobilizations at all, but in new forms of "survival tactics" and social organization based on solidarity and collective self-empowerment, such as neighbourhood food banks, solidarity economy initiatives, alternative currency networks, political experimentation, new alternative media initiatives, and so much more. These initiatives, often inspired by active involvement in the movements of the squares and other forms of resistance to austerity, have potentially 
This is a pre-print versión Please do not cite. To cite this paper please refer to the published version available here: https://www.tandfonline.com/doi/abs/10.1080/14742837.2016.1256193 transformative long-term consequences, long after the squares are empty.

\section{Conclusion: Europe at a cross-roads}

The current wave of European anti-austerity mobilizations shows significant continuities with the GJM, but the impact of the financial crisis has brought the nation -state and the "citizen" as political subject centre stage. At the same time transnational processes of diffusion were very influential, but activists in each locale drew on pre-existing networks and resources, including historical and cultural legacies to adapt and translate new demands and repertoires of action to their own setting. Strong transnational diffusion did not lead to the creation of strong transnational organizations.

Surprisingly, given the role of the Troika in imposing austerity policies (but in keeping with previous findings), "Europe" is less visible than we might expect, but by no means absent, and this visibility varies across cases.

The countering of the crisis/austerity narrative, itself tied to an ideological commitment to the neoliberal state, has, along with a deep questioning of the legitimacy of "really existing democracy", been the most potentially significant characteristic of anti-austerity resistance in Europe in that provides at least the possibility of imagining alternatives to a status quo that satisfies few. I suggest that the extent to which activists managed to combine a critique of austerity with a demand for real or better democracy, they have managed to break with the post-political consensus around the neoliberal state and representative democracy. This rupture has been most visible in the movements of the squares but is not limited 
This is a pre-print versión Please do not cite. To cite this paper please refer to the published version available here: https://www.tandfonline.com/doi/abs/10.1080/14742837.2016.1256193 to them. The influence of the ideas mobilized in the squares has spilled over to many other forms of collective resistance. The challenge to the legitimacy of really existing democracy has produced the most visible consequences of anti-austerity protest: although austerity policies are still firmly in place, the political landscape has been transformed, discursively, in the form of new institutional actors (new or renewed parties), and also mechanisms of counter resistance from the state (e.g. Gag Laws, attacks of freedom of press, expression, assembly), leading to a decrease rather than an increase in certain rights and freedoms. The inability of individual states to stand up to supranational constellations of power such as the Troika, made evident by the case of Greece, has revealed the limitations of national frameworks of resistance to supranational systems of power, and led to calls for a renewed effort to organize transnationally, such as Plan B and efforts at transnational critical Europeanism (Plan B, 2016; Chatzopoulou and Bourne, 2016).

Europe faces a crisis of legitimacy as never before, whether manifest in the withdrawal from the EU of Brexit, whose debates were fuelled by racist, anti-immigrant fear-mongering; the mass outcry against the shameful treatment of refugees arriving (if they are lucky enough to survive the journey) at European shores that highlighted the distance between European leaders and citizens, and the inability of "Europe" to act as one politically; or the plummeting levels of confidence in the EU and national political classes. Progressive anti-austerity and prodemocracy movements are but one possible response to this crisis of legitimacy, just as they are but one, albeit important, cause of it. Europe is at a cross-roads, and collective resistance is more 
This is a pre-print versión Please do not cite. To cite this paper please refer to the published version available here:

https://www.tandfonline.com/doi/abs/10.1080/14742837.2016.1256193 necessary than ever to combat the rising tide of racism and

xenophobia, the relentless attacks on the social welfare state- whose provisions can ameliorate the worst human costs of austerity- and to safeguard guarantees to fundamental rights and freedoms, not least the right to protest itself. Yet all waves of contention subside, subject to a process of fatigue, repression and institutionalization, as well as the actions of counter-movements that seek to maintain the status quo or retreat to an imagined idealized past (i.e. "Let's make [insert nation here] great again").

Tormey (2015) argues that in the wake of the global wave of protests "democracy will never be the same again" and that the crisis of representative politics has transformed the nature of mobilization, contestation and politics itself. I feel it is too soon to tell what the truly transformative impacts of these mobilizations will be, but that at the very least they have opened a breach in the field of hegemonic ideology that has re-politicized civil society and is already producing initiatives for regenerating "really existing democracy", as well as producing strong resistances to changes to the status quo.

Democracy is an empty signifier that anti-austerity and prodemocracy activists, like those in the GJM before them, have tried to re-imbue with specific substantive content. This process of resignification is necessarily long-term, as it involves breaking down existing consensus and generating new ones around alternative systems of meanings. Studying the lessons of European anti-austerity mobilizations and tracing their continuing evolution and consequences will reveal what the nature of democratic "renewal" might be. 
This is a pre-print versión Please do not cite. To cite this paper please refer to the published version available here:

https://www.tandfonline.com/doi/abs/10.1080/14742837.2016.1256193

\section{References:}

Accornero, G., and Ramos Pinto, P. (2015). 'Mild mannered'? Protest and mobilisation in Portugal under austerity, 2010-2013. West European Politics, 38(3), 491-515.

Altersummit EU (2013). "What is the Alter Summit?" Retrieved from: http://www.altersummit.eu/alter-sommet/article/what-is-the-alter$\underline{\text { summit }}$

Armingeon, K., and Guthmann, K. (2014). Democracy in crisis? The declining support for national democracy in European countries, 2007-2011. European Journal of Political Research, 53(3), 423-442.

Atentas, J. (2016) Spain: from the indignados rebellion to regime crisis (2011-2016), Labor History.

Badiou, A. (2005). Being and Event. London: Continuum.

Balbona, D. L., and Begega, S. G. (2016). Crisis Económica Y Coaliciones Anti-Austeridad En España (2010-2014). Sumario Sociología del Trabajo 87, 45.

Baumgarten, B. (2016). The Children of the Carnation Revolution? Connections Between Portugal's Anti-Austerity Movements and the Revolutionary Period 1974/1975. Social Movement Studies, 16

Baumgarten, B. (2013). Geração à Rasca and beyond: Mobilizations in Portugal after 12 March 2011. Current Sociology, 0 (0), 1-17.

Bautista, J. (2016). La Nuit Debout se reorganiza el 15-M (Nuit Debout reorganizes 15-M), La Marea [Online], Retrieved http://www.lamarea.com/2016/05/16/85828/.

Benski, T., Langman, L., Perugorría, I., \& Tejerina, B. (2013). From the streets and squares to social movement studies: What have we learned? Current sociology, 61(4), 541-561.

Blockupy. (2016). Resistance in the Heart of the European Crisis
Formatted: English (UK)

Formatted: Spanish

Formatted: Irish

Formatted: Spanish 
This is a pre-print versión Please do not cite. To cite this paper please refer to the Formatted: English (UK) published version available here: https://www.tandfonline.com/doi/abs/10.1080/14742837.2016.1256193 Regime Retrieved https://blockupy.org/en/

Bourne, A., \& Chatzopoulou, S. (2015). Europeanization and Social movement mobilization during the European Sovereign Debt Crisis: the Cases of Spain and Greece. RECERCA. Revista de Pensament y Anàlisi, (17), 33-60.

Calvo, K. and Álvarez López, I. (2015, March 1). “Nueva política pero viejos perdedores?"[“New politics but old losers?”], eldiario.es [Online], Retrieved from: http://www.eldiario.es/agendapublica/nueva-politica/Nuevapolitica-perdedores-Podemos-mujeres_0_361864204.html.

Chabanet, D., \& Royall, F. (2015). The 2011 Indignés/Occupy Movements in France and Ireland: An Analysis of the Causes of Weak Mobilisations. Modern \& Contemporary France, 23(3), 327-349.

Chatzopoulou, S., \& Bourne, A. (2016). Transnational mobilisation and critical Europeanism. In Euroscepticism As a Transnational and Pan-european Phenomenon. Routledge.

Císař, O. and \& Navrátil, J. (2016), Polanyi, Political Economic Opportunity Structure and Protest: Capitalism and Contention in the Post-communist Czech Republic, Social Movement Studies, 16

Corporate Europe Observatory. (2013). For a European Spring, February 4, Retrieved from (September 9, 2013): https://corporateeurope.org/eu-crisis/2013/02/european-spring

Council of Europe (2013) Commissioner for Human Rights Report, Retrieved from:

https://wcd.coe.int/ViewDoc.jsp?Ref=CommDH(2013)18\&Language $=$ lanSpanish \&Ver=original \&Site=COE \&BackColorInternet=B9BDEE \&BackColorIntranet=FFCD4 F\&BackColorLogged=FF C679. 
This is a pre-print versión Please do not cite. To cite this paper please refer to the

Formatted: English (UK) published version available here:

https://www.tandfonline.com/doi/abs/10.1080/14742837.2016.1256193

Dekker, P., and Feenstra, R. A. (2015). Activism and Civil Society:

Broadening Participation and Deepening Democracy. RECERCA.

Revista de Pensament y Anàlisi, (17), 7-13.

Della Porta, D. (2015). Social movements in times of austerity:

Bringing capitalism back into protest analysis. London: John Wiley \&

Sons.

Della Porta, D. (2013) Can Democracy be Saved: Participation,

Deliberation and Social Movements, Polity, Cambridge.

Della Porta, D. (2012a). Critical trust: Social movements and democracy in times of crisis. Cambio, 2, 33-43.

Della Porta, D. (2012b). Mobilizing against the crisis, mobilizing for "another democracy": Comparing two global waves of protest. Interface, 4(1), 274-277.

Della Porta, D., Mosca, L. and Parks, L. (2012). Same old stories? Trad e unions and protest in Italy in 2011. Retrieved from:

http://www.opendemocracy.net/donatella-della-porta-lorenzomosca-louisa- parks/same-old-stories-trade-unions-and-protest-initaly-2011.

Della Porta, D., and Mattoni, A. (2014). Spreading Protest. Social Movements in Times of Crisis. Colchester: ECPR Press.

Eldiario.es. (2016a). La Nuit Debout de París canta el 'cumpleaños feliz' al 15M, 15 MAY 2016, Retrieved from:

http://www.eldiario.es/rastreador/indignados-franceses-Nuit-

Debout-cumpleanos 6 516258386.html

Eldiario.es (2016b) El Consejo de Informativos de TVE denuncia en Bruselas la manipulación del Gobierno, Retrieved

http://www.eldiario.es/sociedad/Consejo-informativos-TVE-RTVEindependiente 0 377263324.html

Formatted: Default Paragraph Font, Font: $12 \mathrm{pt}$ English (UK)

Formatted: Normal, Space After: 0 pt, Line spacing: single, Pattern: Clear 
This is a pre-print versión Please do not cite. To cite this paper please refer to the Formatted: English (UK) published version available here:

https://www.tandfonline.com/doi/abs/10.1080/14742837.2016.1256193

Electograph. (2016). Iceland Frettablai Poll, October 5, 2016.

Retrieved from: http://www.electograph.com/2016/10/icelandoctober-2016-frettablai-poll.html

Errejón, Í. (2015). "We the People” El 15-M: ¿Un populismo indignado? (15-M an indignant populism?). ACME: An International EJournal for Critical Geographies, 14 (1), 124-156.

Escolar, I. (2016). Las maniobras del PP para enterrar el caso de los discos duros de Bárcenas, (The manoevres of the PP to bury the case of the Bárcenas hard drives) Eldiario.es, Retrieved from:

http://www.eldiario.es/escolar/servicio-Francisco-Granados-discosBarcenas_6_561053918.html

Feigenbaum, A., Frenzel, F., and McCurdy, P. (2013). Protest camps. London: Zed Books.

Fernández-Savater, A. and Flesher Fominaya, C. (Eds.) (2016). Roundtable: Life After the Squares: Reflections on the Consequences of the Occupy Movements, Social Movement Studies, 16,

Flesher Fominaya, C. (2015a). Debunking Spontaneity: Spain's 15M/Indignados as Autonomous Movement. Social Movement Studies, 14 (2): 142-163.

Flesher Fominaya, C. (2015b). "Redefining the Crisis/Redefining Democracy: Mobilizing for the Right to Housing in Spain's PAH Movement" South European Society \& Politics, 20 (4) 465-485.

Flesher Fominaya, C. (2015c). El sentido común, lo "político", el feminismo y el 15-M [Common sense, "the political", feminism, and 15-M] Encrucijadas, Revista Crítica de Ciencias Sociales, 9.

Flesher Fominaya, C. (2014a) Social Movements and Globalization: How Protests, Occupations and Uprisings are Changing the World, London: Palgrave Macmillan. 
This is a pre-print versión Please do not cite. To cite this paper please refer to the Formatted: English (UK) published version available here:

https://www.tandfonline.com/doi/abs/10.1080/14742837.2016.1256193

Flesher Fominaya C. (2014b). Put a Gag on it: Spain's criminalization of 15-M. Red Pepper Magazine. Issue 196: 19.

Flesher Fominaya C. (2014c). Spain is Different: Podemos and 15-M", Open Democracy, May 29, http://opendemocracy.net/can-europemake-it/cristina-flesher-fominaya/\%E2\%80\%9Cspain-isdifferent $\%$ E2\%80\%9D-podemos-and-15m\# ftn6

Freedom House (2016a). Retrieved from:

https://freedomhouse.org/report/freedom-net/2015/turkey

Freedom House (2016b). Retrieved from:

https://freedomhouse.org/report/freedom-world/2016/turkey

Gerbaudo, P. (2016). The Indignant Citizen: Anti-Austerity

Movements in Southern Europe and the Anti-Oligarchic Reclaiming of Citizenship. Social Movement Studies, 16

Glasius, M., and Pleyers, G. (2013). The global moment of 2011:

Democracy, social justice and dignity. Development and Change, 44(3), 547-567.

Habermas J (1975). Legitimation Crisis. Boston: Beacon Press.

Harvey, D. (2007). A brief history of neoliberalism. Oxford University Press, USA.

Hayes, G. (2016). Regimes of Austerity. Social Movement Studies, 16

Imig, D. and S. Tarrow (2000): Political contention in a Europeanising polity. West European Politics, 23(4), pp. 73-93.

Jagers, J., and Walgrave, S. (2007). Populism as political communication style: An empirical study of political parties' discourse in Belgium. European Journal of Political Research, 46(3), 319-345. 
This is a pre-print versión Please do not cite. To cite this paper please refer to the Formatted: English (UK) published version available here:

https://www.tandfonline.com/doi/abs/10.1080/14742837.2016.1256193

Kaldor, M., and Selchow, S. (2013). The 'bubbling up' of subterranean politics in Europe. Journal of Civil Society, 9(1), 78-99.

Kanellopoulos, K., Kostopoulos, K. , Papanikolopoulos, D. and Rongas, V. (2016). Competing modes of coordination in the Greek antiausterity campaign, 2010-2012. Social Movement Studies, 16

Katsiaficas, G. N. (1989). The eros effect. Paper from American Sociological Association Annual Meeting, San Francisco.

Kroll, A. (2011) 'How Occupy Wall Street really got started', MotherJones, 17 October. Retrieved from:

http://www.motherjones.com/politics/2011/10/occupy-wallstreet-international-origins.

Koopmans, R. (2004). Protest in time and space: The evolution of waves of contention. The Blackwell companion to social movements, 19-46.

Langman, L. (2013). Occupy: A new new social movement. Current Sociology, 61, (4) 510-524.

Lawrence, J. (2012) 'El papel del movimiento 15-M en los orígenes de Occupy Wall Street', Interferencias (El.Diario.es), 14 May. Retrieved from: http://www.eldiario.es/interferencias/15-M-

Occupy_Wall_Street_6_132346774.html.

Maeckelbergh, M. (2012). Horizontal democracy now: from alterglobalization to occupation. Interface, 4(1), 207-234.

Martin Rojo, L: (ed). (2016). Occupy The spatial dynamics of discourse in global protest movements. Amsterdam: John Benjamins.

Mattoni, A. (2016). Media practices and protest politics: How precarious workers mobilise. Routledge. 
This is a pre-print versión Please do not cite. To cite this paper please refer to the Formatted: English (UK) published version available here: https://www.tandfonline.com/doi/abs/10.1080/14742837.2016.1256193 Melucci, A., 1994. A strange kind of newness: what's new about the New Social Movements? In: E. Laraña, H. Johnston \& J. Gusfield, eds. 1994. New Social Movements. Philadelphia: Temple University Press.

Mosca, L. (2014). The five star movement: Exception or vanguard in Europe?. The International Spectator, 49(1), 36-52.

Mouffe, C. (2005). On the Political. Abingdon and New York: Routledge.

Norris, P. (2011). Democratic deficit: Critical citizens revisited. Cambridge University Press.

Oikonomakis, L and Roos. J. (2016) "A Global Wave for Real Democracy?" in M. Ancelovici, M., Dufour, P., \& Nez, H.(eds). Street politics in the age of austerity: From the indignados to occupy. Amsterdam: Amsterdam University Press, 227-249.

Oliver, P. E. (1989). Bringing the crowd back in: The nonorganizational elements of social movements. Research in social movements, conflict and change, 11(1989), 1-30.

PAH (2016) Webpage Retrieved http://afectadosporlahipoteca.com/?s=multas

Parsons, N. (2013). Legitimizing illegal protest: the permissive ideational environment and 'bossnappings' in France. British Journal of Industrial Relations, 51(2), 288-309.

Pianta, M., \& Gerbaudo, P. (2015). In Search of European Alternatives: Anti-Austerity Protests in Europe. In Subterranean Politics in Europe (pp. 31-59). Palgrave Macmillan UK.

Pickerill, J., \& Krinsky, J. (2012). Why does Occupy matter?. Social Movement Studies, 11(3-4), 279-287. 
This is a pre-print versión Please do not cite. To cite this paper please refer to the published version available here:

https://www.tandfonline.com/doi/abs/10.1080/14742837.2016.1256193

Plan B (2016). Manifesto. Retrieved from: https://www.europlanb.eu/?page id=96\&lang=en

Polletta, F. (2006). It was like a fever. Storytelling in Protest and Politics. Chicago: University of Chicago Press.

Powell, F. (2015). The Psychopolitics of Austerity: democracy, youth and civil protest. RECERCA. Revista de Pensament y Anàlisi, (17), 1531.

Power, S. (2015) To understand the Eurozone crisis consider culture, Chicago Booth Review, Retrieved from:

http://review.chicagobooth.edu/magazine/summer-2015/tounderstand-the-eurozone-crisis-consider-culture

Rancière, J. (2004). Introducing disagreement 1. Angelaki: journal of the theoretical humanities, 9 (3), 3-9.

Reporteros sin Fronteras (2016) Un año de la 'Ley Mordaza': los periodistas afectados hacen balance Retrieved from:

http://periodismohumano.com/sociedad/libertad-y-justicia/unano-de-la-ley-mordaza-los-periodistas-afectados-hacen-balance.html.

Romanos, E. (2015). Immigrants as brokers: dialogical diffusion from Spanish indignados to Occupy Wall Street. Social Movement Studies, 15 (3), 247-262.

Romanos, Eduardo. (2013). Collective Learning Processes within Social Movements: Some Insights into the Spanish 15-M/Indignados Movement. In C. Flesher Fominaya and L. Cox (Eds.), Understanding European Movements: New Social Movements, Global Justice Struggles, Anti-Austerity Protest. London: Routledge, 203-219.

Scholl, C. (2013). Europe as a Contagious Space: Cross-border diffusion through EuroMayday and climate justice movements. In Flesher Fominaya, C. and Cox, L. (Eds), Understanding European Movements. New York: Routlege, 127-142.
Formatted: English (UK)

Formatted: Font: +Body (Cambria), 14 pt

Formatted: Font: +Body (Cambria), $14 \mathrm{pt}$ 
This is a pre-print versión Please do not cite. To cite this paper please refer to the published version available here:

https://www.tandfonline.com/doi/abs/10.1080/14742837.2016.1256193

Sergi, V., \& Vogiatzoglou, M. (2013). Think globally, act locally?

Symbolic memory and global repertoires in the Tunisian uprising and the Greek anti-austerity mobilizations. In Flesher Fominaya, C. and Cox, L. (Eds), Understanding European movements: new social movements, global justice struggles, anti-austerity protest, 220-235.

Shihade, M., Flesher Fominaya, C., \& Cox, L. (2012). The season of revolution: the Arab Spring and European mobilizations. Interface, 4 (1), 1-16.

Sotirakopoulos, N., \& Sotiropoulos, G. (2013). 'Direct democracy now!': The Greek indignados and the present cycle of struggles. Current Sociology, 0 (0), 1-14.

Stille, A. (2016) Who murdered Giulio Regeni? The Guardian. October 4, 2016. Retrieved from:

https://www.theguardian.com/world/2016/oct/04/egypt-murdergiulio-regeni?CMP=share_btn_fb

Tarrow, S. (1998). Power in movement: social movements and contentious politics. Cambridge: Cambridge University Press.

Tejerina, B., \& Perugorría, I. (2012). Continuities and discontinuities in recent social mobilizations. From new social movements to the alter-global mobilizations and the 15M. From social to political, 93.

Tormey, S. (2015). Democracy will never be the same again: 21st Century Protest and the transformation of Politics. RECERCA. Revista de Pensament y Anàlisi, (17), 107-128.

UN Office of the High Commissioner (2015) "Two legal reform projects undermine the rights of assembly and expression in Spain" Retrieved from:

http://www.ohchr.org/EN/NewsEvents/Pages/DisplayNews.aspx?N ewsID=15597\&LangID=E

Zamponi, L. (2012). Precarious present, uncertain future: multiples dimensions of precarity as a symbolic tool and resource in the Italian university mobilization. In: Tejerina, B. and Perugorría, I. (eds.) From 
This is a pre-print versión Please do not cite. To cite this paper please refer to the

Formatted: English (UK) published version available here:

https://www.tandfonline.com/doi/abs/10.1080/14742837.2016.1256193

Social to Political New Forms of Mobilization and Democratization, Bilbao: Universidad del País Vasco.

\section{Zamponi, L., \& Daphi, P. (2014). Breaks and continuities in and \\ between cycles of protest. Memories and legacies of the global justice movement in the context of anti-austerity mobilisations. In D. Della POrta and A: Mattoni (Eds.), Spreading Protest: Social Movements in Times of Crisis, Colchester: ECPR Press, 193-225.}

Zamponi, L. and Fernández, J. (2016). Dissenting Youth: How Student and Youth Struggles Helped Shape Anti-Austerity Mobilisations in Southern Europe. Social Movement Studies, 16

Žižek, S. (2000). The ticklish subject: The absent centre of political ontology. London: Verso.

Zolberg, A. R. (1972). Moments of madness. Politics and Society, 2(2), 183-207.

\footnotetext{
i Marie Sklodowska Curie Research Project "Contentious Politics in an Age of Austerity: A comparative study of anti-austerity protests in Spain and Ireland" (2013-2015). This research involved extensive participant observation, over 70 interviews and secondary data analysis.

ii See also Císař and Navrátil, this issue.

iii Marie Sklodowska Curie Research Project, as above.

iv By which they mean grassroots activism, protest and various 'new' types of political phenomena not usually visible in mainstream debates.

$\checkmark$ This analysis is drawn from my Marie Sklodowska Curie research.

vi The analysis is this section is drawn from my Marie Sklodowska-Curie research.

vii For more on protest camps, including many in the global movement of the squares, see Feigenbaum, Frenzel and McCurdy (2013).
} 
This is a pre-print versión Please do not cite. To cite this paper please refer to the

Formatted: English (UK) published version available here: https://www.tandfonline.com/doi/abs/10.1080/14742837.2016.1256193

viii I realize that what movements are called are often contested, the result of early media labels, etc. I nevertheless usually opt for the label I think most people will understand.

x I was astonished to discover, during a research event I co-coordinated at Harvard's Berkman Center for Internet and Society in 2012, that some local activists had never heard of the European protests, and thought that the Occupy style movements such as OWS and Occupy Boston were unique to the US.

xi Which could all change in the upcoming elections where they are polling at $22 \%$ at time of writing

xii See the manifesto here: https://www.euro-planb.eu/?page_id=96\&lang=en

xiii But see Power (2015) for why this did not happen in the Irish case. 